\section{Aminoglycoside and chlorhexidine resistance genes in Staphylococcus aureus isolated from surgical wound infections}

\section{Abstract}

Objective: Staphylococcus aureus especially the methicillin-resistant population (MRSA) is a major human pathogen resistant to many antimicrobial agents. This study aims to investigate the prevalence of the aminoglycoside-modifying enzymes (AMEs); genes $\operatorname{aac}\left(6^{\prime}\right)$ aph $\left(2^{\prime}\right)$, aph(3')-IIla, Ant(4')-la) and the biocide (quaternary ammonium compounds) resistance genes (qacA/qacB, qacC) in $S$. aureus isolated from surgical site infections.

Methods: Swabs from 280 infected surgical sites were collected from different surgical words at Mansoura University Hospitals between January 2014 and December 2014). Sixty-six staphylococcal strains were isolated and included in this study. Verification of the presence of methicillin resistance gene (mecA), aminoglycoside resistance genes [(aac( $\left.6^{\prime}\right) / a p h\left(2^{\prime \prime}\right)$, ant $\left(4^{\prime}\right)-1 a$ and aph(3')-IIla)] and qac resistance genes (qacA/qacB, qacC) in S. aureus was carried out by PCR. Chlorhexidine MIC was also determined.

Results: Out of the 66 S. aureus isolates included in this study, 17/66 isolates (25.8\%) were phenotypically characterized as MRSA and mecA gene was detected in 19 S. aureus isolates (28.7\%) by PCR. Aminoglycoside resistant S. aureus accounted for 21/66 (31.8\%) of the isolates. AME genes were detected in all aminoglycoside-resistant S. aureus; aac $\left(6^{\prime}\right) / a p h\left(2^{\prime \prime}\right)$ and was the most frequently detected $11 / 21(52.4 \%)$, followed by aph(3')-IIla 6/21 (28.6\%) and the least frequent was ant (4')-1a 4/21(19\%). Aminoglycoside resistance in 9/21 (42.9\%) of aminoglycoside resistant $S$. aureus isolates was found to be plasmid mediated as proved by plasmid curing experiment. A total of 14/21 aminoglycoside-resistant S. aureus isolates (66.7\%) carried the mecA gene. Nine of the 21 aminoglycoside-resistant S. aureus
Hamdia Askar', Wafaa Badawy2, Enas Hammad ${ }^{1}$

1 Medical Microbiology and Immunology Department, Faculty of Medicine, Mansoura University, Egypt

2 MD. Mansoura University Students' Hospital, Egypt.

Corresponding author:

Dr. Hamida Askar

” hamdiaaskar@yahoo.co.uk 
isolates (42.9\%) were positive for qacA/qacB genes and in all of them mecA gene co-existed.

Five aminoglycoside resistant $S$. aureus isolates were qacC positive (23.8\%). Among the 45 aminoglycoside-sensitive $S$. aureus isolates, 5 (11.1\%) were mecA positive.

Conclusion: This study shows a high proportion of $S$. aureus isolated from infected surgical sites carried aminoglycoside and methicillinresistance genes together with quaternary ammonium compounds resistance genes.

Keywords: Staphylococcal Infections, Surgical Site Infections, Disinfectant Resistance, Drug Resistance.

\section{Introduction}

Staphylococcus aureus is a potentially serious opportunistic human pathogen that colonizes over $30 \%$ of individuals. MRSA is a major nosocomial pathogen that can easily circulate among patients and personnel in hospitals [1].

An important tool in controlling nosocomial MRSA infection is hand hygiene and decontamination of potentially contaminated rooms, utensils and colonized patients. Many antiseptic agents are in use for this purpose but overuse and sub-lethal concentrations of antiseptic agents have led to the emergence of MRSA with decreased antiseptic susceptibility [2].

Multidrug efflux pumps are membrane proteins that form channels to transport toxic compounds such as biocides and disinfectants out of the cell. Their substrates are diverse including quaternary ammonium compounds (Qac) for which they are named [3]. These qac genes, confer resistance to organic cations by means of a proton motive forcedependent multidrug efflux [4]

Within Staphylococcus species, six different plasmid-encoded Qac efflux pumps were known:
QacA and QacB are members of the Major Facilitator Superfamily (MFS) and are highly related and conserved in Staphylococcus species. Whereas, QacC, QacG, QacH, and QacJ belong to the Small Multidrug Resistance (SMR) family. Genes encoding these proteins are generally carried on plasmids $[5,6]$. Some of these plasmids (pST6, pSK4, and pSK41) contain antibiotic resistance genes encoding resistance to gentamicin, penicillin, kanamycin and tobramycin [7].

The qac $A$ and qacB genes are closely related and confer resistance to a range of structurally disparate organic cations, including divalent cations like chlorhexidine. They differ only in the amino acid residue 323 that is (Asp) in QacA and (Ala) in QacB. Both are located on a variety of plasmids and qacA exists also on chromosomes [8].

Chlorhexidine gluconate is a water-soluble cationic bisbiguanide widely used as an antiseptic agent since 1954. It has been approved by the U.S. Food and Drug Administration for infection control in various applications, including general skin cleaning, central venous catheter site preparation, surgical hand and preoperative scrub as well as vascular catheter dressings [9]. Chlorhexidine destroys the 
cell membrane and causes coagulation of intracellular contents of a variety of microorganisms, including Gram-positive and Gram-negative bacteria, lipophilic virus, protozoa, and fungi [10].

The main mechanism of aminoglycoside resistance in staphylococci is the drug inactivation by aminoglycoside-modifying enzymes (AMEs). Among staphylococci, the most common AME is $6^{\prime}-\mathrm{N}$-acetyltransferase-2"-O-phosphotransferase $\left[\operatorname{aac}\left(6^{\prime}\right)-\right.$ aph $\left.\left(2^{\prime \prime}\right)\right]$ that is encoded by aac $\left(6^{\prime}\right)$-aph $\left(2^{\prime \prime}\right)$ gene. This enzyme inactivates amikacin, gentamicin, kanamycin, tobramycin and neomycin. Another AME is $4^{\prime}-O$ adenyltransferase I [ant( $\left(4^{\prime}\right)-I$ ] encoded by ant( (4')-la gene, and it inactivates amikacin, kanamycin, neomycin, and tobramycin. The third AME is 3'-O-III[aph(3')-III] that inactivates amikacin and kanamycin and is encoded by aph (3')-IIla gene [11-13].

The purpose of the present study was to investigate the prevalence of the antiseptic-resistant genes qac $A$, qacB and qac $C$ and aminoglycoside resistance genes in $S$. aureus clinical isolates from surgical site infections at Mansoura University Hospitals.

\section{Materials and Methods}

\section{Sample collection, culture and identification}

This study was approved by the ethical committee of the Faculty of Medicine, Mansoura University. Specimens from infected surgical sites were collected using sterile saline moistened cotton swabs and immediately transported to the laboratory in sterile screw-capped tubes containing $5 \mathrm{ml}$ saline. Specimens were processed at the

Microbiology Diagnostic and Infection Control Unit (MDICU) in the department of Medical Microbiology and Immunology, Mansoura faculty of medicine. Specimens were inoculated within 1-2 $\mathrm{h}$ onto mannitol salt agar and sub-cultured to BairdParker agar medium (Merck, Germany). Plates were incubated aerobically at $37^{\circ} \mathrm{C}$ for 48 hours. Colo- nies with typical black appearance surrounded by a clear zone were considered Staphylococci and when they grow in blood agar they were identified as S. aureus. Further identification of isolates included Gram-stain as well as catalase, and coagulase tests. S. aureus ATCC 12600 was used as positive control and S. epidermidis as a negative control [14].

\section{Antimicrobial susceptibility testing/Disc diffusion method}

Susceptibility tests were performed using the Kirby-Bauer disc diffusion method on Muller-Hinton agar plates which included the following antibiotics: ampicillin/sulbactam $(20 \mu \mathrm{g})$, oxacillin $(1 \mu \mathrm{g})$, gentamicin $(10 \mu \mathrm{g})$, amikacin $(30 \mu \mathrm{g})$, erythromycin $(15 \mu \mathrm{g})$, clindamycin $(2 \mu \mathrm{g})$, chloramphenicol $(30 \mu \mathrm{g})$, ceftazidime (30 $\mu \mathrm{g})$, cefpime $(30 \mu \mathrm{g})$, aztreonam $(10 \mu \mathrm{g})$, imipenem $(10 \mu \mathrm{g})$ trimethoprim-sulfamethoxazole $(25 \mu \mathrm{g})$, fusidic acid $(10 \mu \mathrm{g})$ and vancomycin $(30 \mu \mathrm{g})$ according to Clinical Laboratory Standards Institute guidelines (CLSI) [15]. Antibiotic discs were obtained from (Oxoid, UK). Plates were incubated aerobically at 35 (for oxacillin) and $37^{\circ} \mathrm{C}$ for 24 hours and $\mathrm{S}$. aureus ATCC 12600 was used as quality control strain. Amikacin/kanamycin double resistant strains were used to represent aminoglycosides resistance.

\section{Broth microdilution test}

The minimum inhibitory concentrations (MICs) of chlorhexidine were determined by the reference broth microdilution procedure recommended by the CLSI using 96-well microtiter plates with serial 2-fold dilutions. Dilutions ranged from $32 \mathrm{ug} / \mathrm{ml}$ to $0.25 \mathrm{ug} / \mathrm{ml}$. The MIC was defined as the lowest concentration of antimicrobial agent that produced no visible growth after 20-h incubation in MuellerHinton broth at $37^{\circ} \mathrm{C}$ [15].

\section{DNA manipulation \\ Total DNA extraction}

A single bacterial colony was grown overnight on L-broth with shaking at $37^{\circ} \mathrm{C}$ to stationary phase 
Table 1. Specific PCR primers used for amplification of examined genes

\begin{tabular}{|c|c|c|c|}
\hline Primer's name & $5^{\prime}$ to $3^{\prime}$ Sequence & $\begin{array}{l}\text { Expected amplicon } \\
\text { size }\end{array}$ & Reference \\
\hline $\begin{array}{l}\text { 16S rDNA forward } \\
16 S \text { rDNA reverse }\end{array}$ & $\begin{array}{l}\text { CAG CTC GTG TCG TGA GAT GT } \\
\text { AAT CAT TTG TCC CAC CTT CG }\end{array}$ & $420 \mathrm{bp}$ & GenBank: Y15856 \\
\hline $\begin{array}{l}\text { mecA forward } \\
\text { mecA reverse }\end{array}$ & $\begin{array}{l}\text { GTA GAA ATG ACT GAA CGT CCG ATA A } \\
\text { CCA ATT CCA CAT TGT TTC GGT CTA A }\end{array}$ & $310 b p$ & [18] \\
\hline $\begin{array}{l}\text { qacA/B: forward } \\
q a c A / B: \text { reverse }\end{array}$ & $\begin{array}{l}\text { CTA TGG CAA TAG GAG ATA TGG TGT } \\
\text { CCA CTA CAG ATT CTT CAG CTA CAT G }\end{array}$ & $321 \mathrm{bp}$ & [19] \\
\hline $\begin{array}{l}\text { qacC: forward } \\
\text { qacC: reverse }\end{array}$ & $\begin{array}{c}\text { GGC TTT TCA AAA TTT ATA CCA TCC TAT GCG ATG } \\
\text { TTC CGA AAA TGT }\end{array}$ & $249 b p$ & [20] \\
\hline $\begin{array}{l}\operatorname{aac}\left(6^{\prime}\right) / a p h\left(2^{\prime \prime}\right): \text { forward } \\
\operatorname{aac}\left(6^{\prime}\right) / a p h\left(2^{\prime \prime}\right): \text { reverse }\end{array}$ & $\begin{array}{l}\text { GAA GTA CGC AGA AGA GA } \\
\text { ACA TGG CAA GCT CTA GGA }\end{array}$ & $491 b p$ & [21] \\
\hline $\begin{array}{l}\text { aph(3)-IIla forward } \\
\text { aph(3)-IIla reverse }\end{array}$ & $\begin{array}{l}\text { CGA TGT GGA TTG CGA AAA CT } \\
\text { CAC CGA AAT AAC TAG AAC CC }\end{array}$ & $175 b p$ & [22] \\
\hline $\begin{array}{l}\text { ant }\left(4^{\prime}\right)-1 \text { a forward } \\
\text { ant }\left(4^{\prime}\right)-1 \text { a reverse }\end{array}$ & $\begin{array}{l}\text { ATG GCT CTC TTG GTC GTC AG } \\
\text { TAA GCA CAC GTT CCT GGC TG }\end{array}$ & $367 b p$ & [23] \\
\hline
\end{tabular}

and $1.5 \mathrm{ml}$ culture was harvested by centrifugation at $11600 x \mathrm{x}$ for $2 \mathrm{~min}$ in a microfuge. The manufacturer's recommendations (Sigma) using Thermo Scientific DNA extraction method were used. The extracted DNA was used for PCR amplification of the studied genes including the house-keeping rDNA genes.

\section{Polymerase Chain Reaction (PCR)}

PCR was performed in a $25 \mu$ l reaction volume containing $1 \mu$ l (50 ng) of extracted DNA, $1 \mu$ l of each pair of primers $12.5 \mu \mathrm{l}$ of $2 \mathrm{x}$ Taq premix Mastermix (Sigma) and $9.5 \mu$ sterile double-distilled water. The specific PCR primers and the expected products' sizes are listed in (Table 1). The PCR program involved an initial denaturation step at $95^{\circ} \mathrm{C}$ for 5 min followed by 35 cycles of a denaturation step at $95^{\circ} \mathrm{C}$ for 30 seconds, a primer annealing step at 54- $60^{\circ} \mathrm{C}$ for 30 seconds, an extension step at $72^{\circ} \mathrm{C}$ for 30 seconds, and a final step at $72^{\circ} \mathrm{C}$ for $10 \mathrm{~min}$. In each reaction a positive and a negative control were included as appropriate. The negative control contained all the reagents without template DNA whereas the positive control was the staphylococcal $16 \mathrm{~S}$ rDNA. All PCR products were analyzed by agarose gel electrophoresis using $1.5 \%$ (w/v) agarose, performed at 100v in TAE buffer (0.5M Tris acetate, $5.7 \%$ acetic acid, 10mM EDTA pH 8.0) containing $0.5 \mu \mathrm{g} / \mathrm{ml}$ ethidium bromide.

\section{Plasmid curing}

S. aureus isolates were sequentially passed in LB (approximately 100 cells into $100 \mathrm{ml}$ ) at $43^{\circ} \mathrm{C}$ with shaking for about 30 generations to eliminate the plasmid. Cured strains were diluted and plated on LA plates to obtain single colonies. Replica plating at $37^{\circ} \mathrm{C}$ was used to screen for loss of resistance [16]. Loss of the plasmid was confirmed by loss of unselected phenotypic traits (drug resistance) and by PCR of relevant genes [17]. All statistical analyses were performed using SPSS version 16.0 (SPAA Inc., Chicago, IL, USA), using Chi square and Independent sample $T$ tests. $p$ - value $<0.05$ is considered significant. 


\section{Results}

A total of 280 swabs were collected from infected surgical sites at different surgical departments of Mansoura University Hospitals. S. aureus was isolated from 66 (23.6\%) samples. S. aureus isolates resistant to both amikacin and kanamycin were used to represent aminoglycosides resistance. The genes for aminoglycoside modifying enzymes $\left(\operatorname{aac}\left(6^{\prime}\right) / a p h\left(2^{\prime \prime}\right)\right.$, aph(3')-IIla and Ant(4')-la) were carried by 21/66 ( $31.8 \%$ ) S. aureus isolates. Among these genes $\operatorname{aac}\left(6^{\prime}\right) / a p h\left(2^{\prime \prime}\right)$ was the most

frequent being detected in 11/21 (52.4\%) of aminoglycoside resistant $S$. aureus followed by aph(3')-
IIla that was positive in 6/21 (28.6\%) while ant(4')-la was the least common, only detected in 4/21(19\%) of aminoglycoside resistant $S$. aureus (Table 2). Genes for quaternary ammonium compounds resistance were detected in 14/21 aminoglycoside resistant S. aureus (66.7\%); qacA/qacB was detected in 9/21 (42.9\%) and qacC was detected by PCR in 5/21 (23.8\%). The antimicrobial susceptibility patterns of the 66 S. aureus isolates by disc diffusion revealed 17 oxacillin resistant isolates (MRSA) (25.8\%). The mecA gene was detected by PCR in the genomic DNA of $19 \mathrm{~S}$. aureus isolates (28.7\%). mecA gene was detected in 14/21 (66.7\%) aminoglycosides resistant isolates as shown in (Table 3). Genes for re-

Table 2. The relationship between aminoglycoside resistance pattern and the presence of aminoglycoside-modifying enzymes genes in S. aureus isolates.

\begin{tabular}{|c|c|c|c|c|c|}
\hline \multirow{3}{*}{$\begin{array}{l}\text { S. aureus } \\
\text { isolates }\end{array}$} & \multirow{2}{*}{$\begin{array}{l}\text { Aminoglycoside } \\
\text { susceptibility }\end{array}$} & \multicolumn{3}{|c|}{ Aminoglycoside-modifying enzymes genes } & \multirow{2}{*}{$\begin{array}{l}\text { PCR negative } \\
\text { isolates }\end{array}$} \\
\hline & & $\operatorname{aac}\left(6^{\prime}\right) / a p h\left(2^{\prime \prime}\right)$ & aph(3')-IIIa & Ant(4')-la & \\
\hline & N (\%) & N (\%) & N (\%) & N (\%) & N (\%) \\
\hline Resistant & $21(31.8 \%)$ & $11(52.4 \%)$ & $6(28.6 \%)$ & $4(19 \%)$ & 0 \\
\hline Sensitive & $45(68.2 \%)$ & $6(13.3 \%)$ & $2(4.4 \%)$ & $1(2.2 \%)$ & $36(80 \%)$ \\
\hline Total & 66 & $17(25.8 \%)$ & $8(12.1 \%)$ & $5(7.6 \%)$ & $36(54.5 \%)$ \\
\hline
\end{tabular}

$p$ - value $<0.001$ for the test of homogeneity of the 3 types of AME genes in S. areus

Table 3. Frequencies of methicillin and quaternary ammonium compounds resistance genes among aminoglycoside resistant $S$. aureus

\begin{tabular}{|c|c|c|c|c|c|c|c|}
\hline \multirow{4}{*}{ Isolates } & & & \multirow{2}{*}{\multicolumn{2}{|c|}{ Methicillin resistance gene }} & \multicolumn{3}{|c|}{$\begin{array}{l}\text { Quaternary ammonium resistance } \\
\text { genes }\end{array}$} \\
\hline & \multicolumn{2}{|c|}{$\begin{array}{l}\text { Aminoglycoside } \\
\text { resistance }\end{array}$} & & & \multicolumn{2}{|c|}{ Positive } & \multirow[t]{2}{*}{ Negative } \\
\hline & & & mecA(+ve) & mecA (-ve) & qacA/qacB & qacC & \\
\hline & & & N (\%) & N (\%) & N (\%) & N (\%) & N (\%) \\
\hline \multirow[t]{2}{*}{$\begin{array}{l}\text { S. aureus } \\
(66)\end{array}$} & Resistant N/ \% & $\begin{array}{c}21 \\
(31.8)\end{array}$ & $14(66.7)$ & $7(33.3)$ & $9(47.4)$ & $5(28.9)$ & $7(23.7)$ \\
\hline & Sensitive N/ \% & $\begin{array}{c}45 \\
(68.2)\end{array}$ & 5 (11.1) & 40 (88.9) & ------------ & ------- & $45(100)$ \\
\hline
\end{tabular}

$p$ - value $<0.001$ 
Table 4. The frequencies of quaternary ammonium compounds resistance genes among methicillin resistant $S$. aureus

\begin{tabular}{|c|c|c|c|c|c|}
\hline \multirow{3}{*}{ S. aureus isolates } & \multirow{3}{*}{\multicolumn{2}{|c|}{$\begin{array}{l}\text { Methicillin } \\
\text { resistance gene (mecA) }\end{array}$}} & \multicolumn{3}{|c|}{ Quaternary ammonium resistance genes } \\
\hline & & & \multicolumn{2}{|c|}{ Positive/ N (\%) } & Negative-/N (\%) \\
\hline & & & qacA/qacB & qacC & \multirow{2}{*}{$5(26.3)$} \\
\hline \multirow[t]{2}{*}{ (66) } & (+ve) N (\%) & $19(28.7)$ & $9(47.4)$ & $5(26.3)$ & \\
\hline & $(-\mathrm{ve}) \mathrm{N}(\%)$ & $47(61.3)$ & - & - & $47(100)$ \\
\hline
\end{tabular}

sistance to quaternary ammonium compounds were found in 14/19 (73.7\%) methicillin resistant S. aureus. qacA/qacB genes was detected in 9/19 (47.4\%) and qacC gene was detected in 5/19 (26.3\%) of MRSA isolates (Table 4).

The MIC for chlorhexidine ranged from 1 to 8 $\mathrm{ug} / \mathrm{ml}$ while that for the standard $\mathrm{S}$. aureus ATCC 12600 was 2 mg/ml. All aminoglycoside and methicillin sensitive $S$. aureus isolates did not carry any quaternary ammonium compound resistance genes and their MIC for chlorhexidine was <2ug/ml. Plasmid curing experiment eliminated AMEs genes and aminoglycoside resistance in 9/21 (42.9\%) of aminoglycoside resistant $S$. aureus isolates.

\section{Discussion}

Aminoglycosides have an important role in the treatment of $S$. aureus associated surgical site infections in many countries including Egypt. There is a limited amount of data regarding the prevalence of aminoglycosides resistance genes (AMEs genes) among $S$. aureus clinical isolates in Egypt. The results of this study shows that $S$. aureus isolated from infected surgical wounds were positive at a high rate for presence of aminoglycosides and methicillin-resistance genes (66.7\%) in association with quaternary ammonium compounds resistance genes. Two thirds of the aminoglycoside resistant $S$. aureus tested in this study carried the mecA gene together with one of the AME genes. None of the $S$. aureus isolated in this work carried more than one AME gene. Other similar studies reported $\operatorname{aac}\left(6^{\prime}\right) /$ aph $\left(2^{\prime \prime}\right)$ as the most frequently detected AME gene $(83 \%)$ among $S$. aureus isolates [24, 25]. Some studies reported a prevalence of the three AME genes in $21 \%$ of isolates [26].

The co-existence of mecA gene and AME genes in a relevant number of tested $S$. aureus might suggest a genetic linkage as the mecA gene in MRSA is carried on the Staphylococcal Cassette Chromosome mec that encodes genes for other antibiotics including aminoglycosides [27]. Plasmid curing experiment eliminated AME genes and aminoglycoside resistance in (42.9\%) of aminoglycoside resistance $S$. aureus isolates. This result confirmed the carriage of these genes on plasmids, and it is alarming since the horizontal gene transfer by plasmids is highly increasing the risk of drug resistant strain dissemination [28].

Quaternary ammonium compounds are commonly used disinfectants in hospitals to control hospital-associated infection but resistance to these compounds has lately increased [29]. Moreover, it is frequently linked to resistance to other antibiotics such as methicillin and aminoglycosides. However, inconsistent results were reported regarding the frequencies of antiseptic resistance genes including qac $A / B$ and qacC genes in $S$. aureus in different countries and hospitals $[2,30]$.

A study carried out by Noguchi et al. [2], reported 
an occurrence rate of qac $A / B$ and qac $C$ genes in Asian isolates to be $41.6 \%$ and $1.9 \%$, respectively [2]. In our study qac $A / B$ was more frequent than qacC and was detected in $47.4 \%$ of MRSA isolates, whereas qacC was positive only in $28.9 \%$ of those isolates. In agreement with this but with lower frequencies, Duran et al. [21] reported the isolation of qac $A / B$ at a higher rate than qacC from MRSA with qacA/B (20.8\%), while qacC gene existed at the frequency of $7.7 \%$ [29]. A Malaysian study showed much higher rate of detection for qac $A / B$ gene among their MRSA isolates (83.3\%), and only $1.9 \%$ of these strains were positive for qacC [31]. On the other hand, the study of Nakipoğlu et al., [32] reported an isolation rate of (36\%) for qacC in MRSA isolates, while qacA/B was detected only in $4 \%$ of those isolates. Along with our results, a recent study reported the presence of antiseptic resistance genes in $68.4 \%$ of the aminoglycosides resistant MRSA isolated from surgical site infections, among of these $47.4 \%$ carried qac $A / B$ and $28.9 \%$ were gacC positive [29].

In conclusion, the current work demonstrates that $66.7 \%$ of the aminoglycoside resistant S. aureus isolated from surgical site infections were harboring genes for antiseptic resistance and $42.8 \%$ and $23.8 \%$ were positive for qac $A / B$ and qacC, respectively.

\section{References}

1. Nystrom B. Impact of handwashing on mortality in intensive care: examination of the evidence. Infect Control Hosp Epidemiol 1994;15: 435-436.

2. Noguchi N, Suwa J, Narui K, Sasatsu M, Ito T, et al. Susceptibilities to antiseptic agents and distribution of antiseptic-resistance genes qacA/B and smr of methicillin-resistant Staphylococcus aureus isolated in Asia during 1998 and 1999. J Med Microbiol 2005; 54(Pt 6): 557-65

3. Nakaminami $H$, Noguchi $N$, Sasatsu M. Fluoroquinolone efflux by the plasmid-mediated multidrug efflux pump QacB variant QacBIII in Staphylococcus aureus. Antimicrob Agents Chemother 210; 54(10):4107-11.

4. Mitchell BA, Brown MH, Skurray, RA. (1998): qacA multidrug efflux pump from Staphylococcus aureus: comparative analysis of resistance to diamines, biguanides, and buanylhydrazones. Antimicrob Agents Chemother 1998; 42: 475-7.

5. Leelaporn A, Firth N, Paulsen IT, Hettiaratchi A, Skurray RA. Multidrug resistance plasmid pSK108 from coagulase-negative staphylococci; relationships to Staphylococcus aureus qacC plasmids. Plasmid 1995; 34:62-67.

6. Noguchi N, Hase M, Kitta M, Sasatsu M, Deguchi K, Kono M Antiseptic susceptibility and distribution of antiseptic-resistance genes in methicillin-resistant Staphylococcus aureus. FEMS Microbiol Lett 1999; 172:247-253.

7. Berg T, Firth $N$, Apisiridej S, Hettiaratchi A, Leelaporn A, et al. Complete nucleotide sequence of pSK41: Evolution of staphylococcal conjugative multiresistance plasmids. J Bacteriol 1998; 180:4350-4359

8. Paulsen, I. T., Brown, M. H., Littlejohn, T. G., Mitchell, B. A. \& Skurray, R. A. Multidrug resistance proteins QacA and QacB from Staphylococcus aureus: membrane topology and identification of residues involved in substrate specificity. Proceedings of the National Academy of Sciences, USA 1998; 93: 3630-5.

9. Milstone AM, Passaretti CL, Perl TM. Chlorhexidine: expanding the armamentarium for infection control and prevention. Clin Infect Dis 2008; 46:274-281.

10. McDonnell G, Russell AD. Antiseptics and disinfectants: activity, action, and resistance. Clin Microbiol Rev 1999; 12:147-179.

11. Kim HB, Kim $T$, Lee $B B$, et al. Frequency of resistance to aminoglycoside antibiotics in Staphylococcus aureus isolates from tertiary hospitals. Korean J Infect Dis 2002; 34:39-46.

12. Choi SM, Kim SH, Kim HJ, et al. Multiplex PCR for the detection of genes encoding aminoglycoside modifying enzymes and methicillin resistance among Staphylococcus species. J Korean Med Sci 2003; 18:631-36.

13. Sekiguchi J, Fujino T, Saruta K, Konosaki H, Nishimura $H$, et al. Prevalence of erythromycin-, tetracycline-, and aminoglycosideresistance genes in methicillin-resistant Staphylococcus aureus in hospitals in Tokyo and Kumamoto. Jpn J Infect Dis 2004; 57:74-77.

14. Bianchi DM, Gallina S, Bellio A, Chiesa F, Civera T, Decastelli L. Enterotoxin gene profiles of Staphylococcus aureus isolated from milk and dairy products in Italy. Lett Appl Microbiol 2014; 58(2):190-196.

15. Clinical and Laboratory Standards Institute. Methods for dilution antimicrobial susceptibility tests for bacteria that grow aerobically. Approved standard M7-A7. Clinical and Laboratory Standards Institute, Wayne, PA, 2006

16. Spengler G, Molnar A, Schelz Z, Amaral L, Sharples D, Molnar J. The mechanism of plasmid curing in bacteria. Curr. Drug. Targets 2006; 7: 1-19.

17. Lannergard J, Norstrom T, Hughes D. Genetic determinants of resistance to fusidic acid among clinical bacteremia isolates of Staphylococcus aureus. Antimicrob Agents Chemother 2009;53(5):2059-2065.

18. Geha DJ, Uhl JR, Gustaferro CA, Persing DH. Multiplex PCR for identification of methicillin-resistant staphylococci in the clinical laboratory. J Clin Microbiol 1994; 32(7):1768-72. 
19. Rouch DA, Cram DS, DiBerardino D, Littlejohn TG, Skurray RA. Efflux-mediated antiseptic gene qacA from Staphylococcus aureus: common ancestry with tetracycline- and sugartransport proteins. Mol Microbiol 1990; 4, 2051-2062.

20. Zmantar T, Kouidhi B, Miladi H, Bakhrouf A. Detection of macrolide and disinfectant resistance genes in clinical. Staphylococcus aureus and coagulase-negative staphylococci. BMC Res Notes 2011; 4:453-64.

21. Duran N, Ozer B, Duran GG, Onlen Y, Demir C. Antibiotic resistance genes \& susceptibility patterns in staphylococci, Indian J Med Res 2012; 135.389-96.

22. Gray G S, Fitch W M. Evolution of antibiotic resistance genes: the DNA sequence of a kanamycin resistance gene from Staphylococcus aureus. Mol Biol Evol 1984; 1:57-66

23. Matsumura $M$, Katakura $Y$, Imanaka $T$, Aiba S. Enzymatic and nucleotide sequence studies of a kanamycin-inactivating enzyme encoded by a plasmid from thermophilic bacilli in comparison with that encoded by plasmid pUB110. J Bacteriol. 1984;160:413-420.

24. Fatholahzadeh B, Emaneini $M$, Feizabadi MM, Sedaghat $H$, Aligholi $M$, et al. Characterisation of genes encoding aminoglycoside-modifying enzymes among meticillin-resistant Staphylococcus aureus isolated from two hospitals in Tehran, Iran. Int J Antimicrob Agents 2009;33:264-5.

25. Carneiro LA, Queiroz ML, Merquior VL. Antimicrobial-resistance and enterotoxin-encoding genes among staphylococci isolated from expressed human breast milk. J Med Microbiol 2004; 53:761-8.

26. Emaneini M, Bigverdi R, Kalantar D, Soroush S, Jabalameli F, et al. Distribution of genes encoding tetracycline resistance and aminoglycoside modifying enzymes in Staphylococcus aureus strains isolated from a burn center. Ann Burns Fire Disasters 2013; 30;26(2):76-80

27. Fatholahzadeh B, Emaneini M, Gilbert G, Udo E, Aligholi M et al. Staphylococcal cassette chromosome mec (SCCmec) analysis and antimicrobial susceptibility patterns of methicillin-resistant Staphylococcus aureus (MRSA) isolates in Tehran, Iran. Microb Drug Resist 2008;14:217-20.

28. Gómez-Sanz E, Kadlec K, Feßler AT, Zarazaga M, Torres $C$, et al. Novel erm(T)-Carrying Multiresistance Plasmids from Porcine and Human Isolates of Methicillin-Resistant Staphylococcusaureus ST398 That Also Harbor Cadmium and Copper Resistance Determinants. Antimicrob Agents Chemother 2013; 57(7):3275-82.

29. Duran N, Temiz M, Duran GG, Eryılmaz N, Jenedi K. Relationship between the resistance genes to quaternary ammonium compounds and antibiotic resistance in staphylococci isolated from surgical site infections Med Sci Monit 2014; 20:544-50.

30. Zhang M, O'Donoghue MM, Ito T, Hiramatsu K, Boost MV. Prevalence of antiseptic-resistance genes in Staphylococcus aureus and coagulase-negative staphylococci colonising nurses and the general population in Hong Kong. J Hosp Infect 2011;78(2): 113-17

31. Shamsudin MN, Alreshidi MA, Hamat RA, Alshrari AS, Atshan SS, et al. High prevalence of qacA/B carriage among clinical isolates of meticillin-resistant Staphylococcus aureus in Malaysia. J Hosp Infect 2012; 81(3):206-8.

32. Nakipoğlu Y, Ignak S, Gürler N, Gürler B. The prevalence of antiseptic resistance genes (qac $A / B$ and $s m r$ ) and antibiotic resistance in clinical Staphylococcus aureus strains Mikrobiyol Bul 2012; 46:180-89 (Turkish).

\section{Comment on this article:}
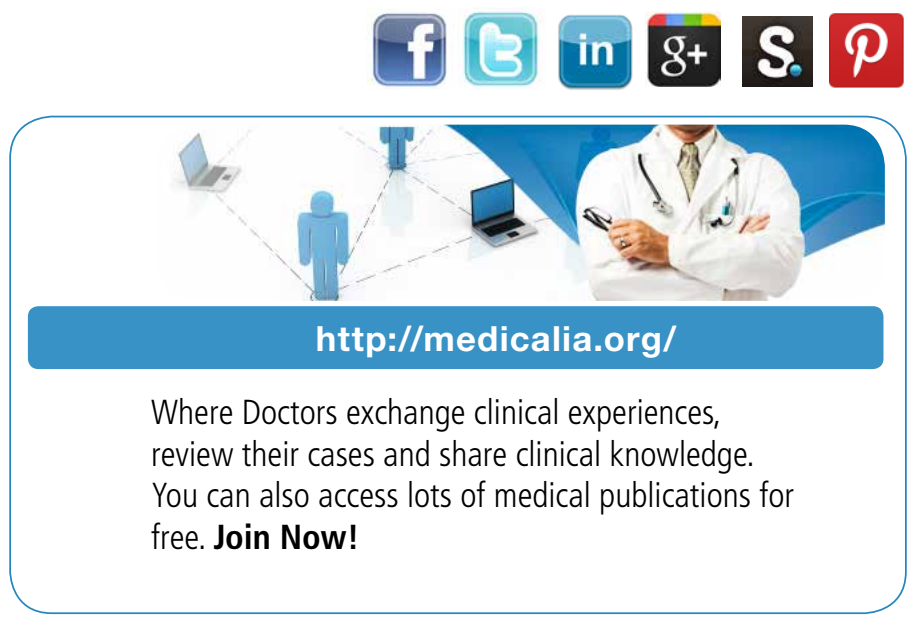

\section{Publish with iMedPub}

\section{http://www.imed.pub}

The Journal is an open access peer-reviewed journal that publishes scientific papers about all aspects of antimicrobials. The journal will publish original research articles, reviews, brief reports and case reports dealing with basic and clinical antibacterial agents, antiviral, antiprotozoals, antituberculuous, antifungal and antihelminthes agents.

All manuscripts must be prepared in English, and are subject to a rigorous and fair peer-review process. Accepted papers will immediately appear online.

The journal aims to advance the knowledge, attitude and the research of chemotherapy in the Arabic world in cooperation with international, national scientific and public societies as well as research centers with similar aims and objectives. 